University of Wollongong

Research Online

Faculty of Commerce - Papers (Archive)

Faculty of Business and Law

June 2003

\title{
A Documentary of Innovation Support Among New World Wine Industries
}

D. K. Aylward

University of Wollongong, daylward@uow.edu.au

Follow this and additional works at: https://ro.uow.edu.au/commpapers

Part of the Business Commons, and the Social and Behavioral Sciences Commons

\section{Recommended Citation}

Aylward, D. K.: A Documentary of Innovation Support Among New World Wine Industries 2003.

https://ro.uow.edu.au/commpapers/8

Research Online is the open access institutional repository for the University of Wollongong. For further information contact the UOW Library: research-pubs@uow.edu.au 


\title{
A Documentary of Innovation Support Among New World Wine Industries
}

\begin{abstract}
During the past two decades, the international wine industry has undergone a 'seismic shift'. Old World producers no longer dominate production, export and marketing of wine to the extent that they once did. Instead, New World producers such as California, South Africa, Australia and New Zealand have successfully married production, management, marketing and innovation to emerge as a new force on the global wine landscape. It is the innovation supports within these selected New World industries that this paper seeks to document, in order to highlight different approaches and outcomes and how they may or may not contribute to an innovative culture.
\end{abstract}

\section{Keywords}

Wine, R\&D, innovation, infrastructure, New World, knowledge

Disciplines

Business | Social and Behavioral Sciences

\section{Publication Details}

This article was originally published as Aylward, D, A Documentary of Innovation Support Among New World Wine Industries, Journal of Wine Research, 14(1), 2003. Copyright Taylor \& Francis. This journal is available online here. 
A Documentary of Innovation

Support Among New World Wine Industries

David K. Aylward

Research Manager,

Faculty of Commerce,

University of Wollongong 


\begin{abstract}
During the past two decades, the international wine industry has undergone a 'seismic shift'. Old World producers no longer dominate production, export and marketing of wine to the extent that they once did. Instead, New World producers such as California, South Africa, Australia and New Zealand have successfully married production, management, marketing and innovation to emerge as a new force on the global wine landscape.
\end{abstract}

It is the innovation supports within these selected New World industries that this paper seeks to document, in order to highlight different approaches and outcomes and how they may or may not contribute to an innovative culture.

Keywords: Wine, R\&D, innovation, infrastructure, New World, knowledge

\author{
Contact author: \\ David K. Aylward \\ Faculty Research Manager, \\ Faculty of Commerce \\ University of Wollongong \\ Wollongong, NSW 2522 \\ Australia \\ Phone (61 2) 42214354 \\ Fax (61 2) 42214157 \\ David_aylward@uow.edu.au
}




\section{A Documentary of Innovation}

\section{Support among New World Wine Industries}

\section{Introduction}

Over the past two decades, production systems have become increasingly knowledgeintensive. Knowledge, skills and training at the personal and firm level are being valued for their contribution to the 'innovative capacity' of the system as a whole.

Since 1985, when it was first introduced by Bengt-Ake Lundvall, the concept of a 'national innovation system' has emerged as one of the more significant innovation theories of our time (Lundvall, B, 1999). However, while this theory can be applied successfully to a number of more traditional industry sectors, it falls short when attempting to understand the complexity of innovative relationships in emerging and high growth wine industries.

The increasingly interactive relationship between wine R\&D institutions and the industry's production system may be better understood conceptually by what is referred to as an ‘innovation territories’ approach (Marceau \& Martinez-Fernandez, 2002). Such a concept allows for broader patterns of interaction for different levels and types of innovation across different economic 'spaces', regions and countries (Marceau \& Martinez-Fernandez, 2002). Its analytical framework includes among others, technology and industrial spread, knowledge production and transmission, financial services, production and consumption, infrastructure and human capital. Such a framework allows us to move beyond the simple geographical distribution of innovation to understand instead its fluid interaction in all of its forms - a framework that fits comfortably with New World wine R\&D. 
'New World' wine industries effectively demonstrate the 'innovation territories' concept by establishing successful interaction between suppliers, producers, industry organisations, R\&D institutions and government agencies at the local, regional and national levels. By supporting the sector and generating interaction between locations these stakeholders help to foster an innovative culture. This approach is feeding a growing nexus between innovation and export performance $-\mathrm{a}$ factor that is placing these operators in increasingly stark contrast with their old World competitors.

\section{Background}

The 'international wine industry' has been undergoing a significant restructuring. No longer do Old World producers such as Italy, France, Spain and Germany dominate the industry to the extent that they once did. No longer are New World producers such as Australia, New Zealand, South Africa and California regarded with the contempt that they once were. Indeed, over the past decade there has been a seismic shift in the international production, export and consumption of wine.

One factor contributing to this shift is the innovative way in which a number of New World producers have embraced a range of R\&D practices, including improved viticultural and oenological techniques and management, high level training, knowledge transmission and technology transfer. The preparedness and ability of many New World producers to trial and implement many of these practices is complementing their bold approach to branding and global marketing.

It is also apparent that at least in some New World industries, wine and winegrape production is becoming embedded within an environment of innovation that is being supported and managed at the national level (in Australia for example, the Federal Government matches the 
producer levy dollar for dollar to a maximum of $0.5 \%$ of gross output value). (Anderson, 2001). Strong links are being generated between producers and users, while the distribution of business, marketing and technological information between them is becoming increasingly coherent. In at least one country the recent raising of the research levy for producers will help to underscore this growing culture of innovation by capitalising on the already significant intermediary body's annual $\$ 10$ million budget (Anderson, $2000 \& 2001$ ). Other New World producers, particularly California and New Zealand, are already looking to this model for guidance.

\section{The Wine Industry's 'Seismic Shift'}

Wine is still primarily an 'Old World' product, with the majority of production, trade and consumption involving European wine giants such as Italy, France, Spain and Germany (Anderson 1999). Over the past two decades and particularly the last decade, however, Europe's dominance has been increasingly eroded not only in terms of absolutes, such as production, litres consumed and export sales, but more particularly in the perception of change.

In value terms, Europe's late 1980s share of exports was approximately 96\% (Anderson, Norman, Wittwer, 2002). In 2000, it was 68.1\% (Winetitles, 2002). As Anderson et al claim, if you exclude intra-EU trade the European export figure is now closer to $48 \%$ Anderson, Norman, Wittwer, 2002). In that same period Australia's wine exports have risen by around 1,132\% from 40 million litres to 453 million litres (Winetitles, 2002). The increase was even greater in value of exports, rising from around \$25 million to \$2 billion. For New Zealand, the past decade has seen a quadrupling of exports, which now account for $34 \%$ of all NZ sales. 
There was also a transfer in wine production, with falls in France, Italy and a number of other Old World producers, while Australia, New Zealand, California and Chile enjoyed substantial production increases (Californian Wine Institute, 2002). More significantly, most industry analysts expect these trends, particularly in export, to accelerate over the next ten years. This will be seen most dramatically in the lucrative markets of the UK, USA, Canada, Germany and Japan.

But figures alone fail to convey the importance of this shift. The real importance lies in what the shift signals, and that is the end of Europe's monopoly on wine culture. This culture has been democratised and is now embraced by most of the developed world, represented equally by the bold branding, innovative techniques and fresh new flavours of many New World producers.

\section{What's Behind the Shift?}

So why the shift in production and export? Why the dramatic shift in wine culture? The reasons are numerous. A transfer in demand is the obvious determinant. Customers are showing an increasing preference for New World wine with a perception that it offers uniqueness, value for money, quality and innovative blending. These are obvious factors contributing to the shift, but other, less tangible factors, include the level of Research and Development $(R \& D)$ within the industry and the transmission of that R\&D between industry bodies, government organisations and firms at local, regional and national levels. These 'innovation territories' are the focus of this article.

R\&D infrastructure, information and knowledge transfer and the take-up of both product and process innovation all contribute to the surge in New World wine production, export and branding. We can look to viticulture, with unique techniques for soil and vine analysis, and disease and pest control, or to wine-grape production with an emphasis on new technologies, 
processes, information, system sustainability and production efficiency. We can look to extension and training packages for regional firms, or to the branding and marketing of the final product (GWRDC 2001). The effective arrangement and interaction of these 'innovation territories' contribute to the ongoing success of New World products.

Because New World producers, by definition, are not locked into the localised viticultural and oenological traditions of many European producers there is a greater readiness to embrace and experiment with new technologies. As is becoming increasingly apparent, the successful implementation of these new technologies and the coordination of their use, is leading to better quality wine at a more affordable price, more diverse blending, greater uniformity within each label, and increased flexibility of production.

Failing to discriminate, however, between New World producers and the degree to which they adopt these innovative practices would be wrong. Just as a small number of traditional European producers are adopting some modern innovation and management practices in order to compete more effectively, not all New World producers are embracing and coordinating this innovation with the same effectiveness or enthusiasm.

\section{Aims of the Study}

In documenting innovation territories among selected New World producers, this study asks which producers appear to be embracing and coordinating innovation within their industry most effectively. (Throughout the paper, 'innovation' and R\&D will be interpreted broadly to include product and process innovation, knowledge transfer and R\&D infrastructure).

To provide at least preliminary answers to this question, the study examines $R \& D$ mechanisms and infrastructure/innovation support in four selected New World wine 
industries - Australia, New Zealand, California and South Africa. Specifically, this will include:

1. Comparing levels of innovation and coordination among New World producers

2. Gauging how well firms within each of the four regions appear to be serviced by their respective industry bodies in terms of technology transfer and R\&D infrastructure

3. Determining R\&D infrastructure 'leadership' among the selected New World producers

\section{Methodology of the Study}

A survey questionnaire was devised, building on one used by the author in a previous study on R\&D diffusion in the Australian wine industry. The survey focused on the examination of wine firm perceptions alone, as the major clients of R\&D support and dissemination.

- The survey was distributed to approximately 244 firms -61 to each selected New World producer.

- 120 firms responded - Australia (48), New Zealand (30), South Africa (17) and California (25).

- Previous experience in surveying the wine industry suggests that wine operators have a fairly intimate knowledge of the status and structure of their industry, compared with other industry respondents and this size survey appears adequate for the proposed analysis.

- Survey Firm Characteristics: Survey firms included sole proprietors, incorporated companies, subsidiaries and publicly listed companies. Firms ranged in size from owner-operated, single employee boutique firms, through small, medium and large firms within each of the four selected New World regions. In each of the four sample groups, firms were selected across a geographically diverse spectrum in order to gain representation from as many regions as possible. Even though the number of respondents was less than the number distributed to, the integrity of this diversity was 
maintained, as was diversity of firm size. Greater representation from some of the sample groups was also taken into consideration.

- Responses were examined using a number of variables, including country, question type, firm size, levels of R\&D coordination and number of industry bodies within each operator sector.

\section{Overview of Selected New World Producers}

\section{California}

This now massive industry had its shaky beginnings back in 1769 , when Fr. Junipero Serra brought vines with two-century old lineage from Baja to the Californian coast (Mojave Internet 2002). For the next 70 years the young industry developed slowly and sporadically, with gradual settlements at Sonoma and Napa, but with no systematic plantings (Mojave Internet 2002).

California now represents the heart of wine production in the US, accounting for over $90 \%$ of the total output and $96 \%$ of its exports (Wine Institute, The Voice of California Wine, 2001) and lifting the US to the fourth largest wine producer in the world.

\section{Research and Development}

The Californian wine boom was in full swing by the 1960s and the wines were soon outclassing many of their European competitors. Much of this credit may be attributed to California's 'scientific approach' to what had always been a 'lifestyle' industry (Wine Institute, The Voice of California Wine, 2001). Today, research and development in the Californian wine industry is significant. R\&D is serviced by bodies such as:

- the Californian Association of Winegrape Growers, responsible for advocacy, research and networking; 
- the American Vineyard Foundation, which is a non-profit organisation responsible for carrying out basic and applied research (American Vineyard Foundation Home Page 2002)

- the American Vintners Association (now Wine America) whose role is to promote policy developments beneficial to the wine industry (Wine America Home Page 2002).

- the famous University of California - Davis which carries out leading edge scientific research focused on benefits to the wine industry.(Wine Institute, The Voice of California Wine, 2001).

The institutions service a significant industry that boasts 847 wineries, 905,000 acres under vine, produces over 533 million gallons of wine, provides 145,000 equivalent full time jobs and has an export market worth around \$500 million (Wine Institute Online, The Voice of California Wine, Statistical Highlights, 2001).

\section{South Africa}

The establishment of a victualling station in South Africa by the Dutch East India company in 1652 led circuitously to what is today a promising New World wine operator. As the first Governor of the Cape, Jan van Riebeeck planted vineyards in 1655 and by 1659 the first Cape wine was being made. Since then the South African wine industry has grown into the eighth largest producer in the world (Winenet, 2002).

Today, there are roughly 105,000 hectares under vine with about 950 million litres produced annually. The production is handled largely by 82 estates and 70 cooperative cellars, pressing roughly $85 \%$ of the total wine harvest. Recent estimates suggest that the wine industry's contribution to the total horticultural income for South Africa is $30 \%$ (Winenet, 2002). About 208,000 people are employed both directly and indirectly in the industry. 
At the heart of the industry, is a state research body, the Nietvoobij Institute for Viticulture and Oenology, which employs approximately 230 people. This institute is linked to the departments of viniculture and viticulture at the University of Stellenbosch, as well as the Elsenburg Agricultural College and has a 12-man advisory team from KWV (Winenet 2002). In addition, there is the South African Wine Industry Trust (SAWIT), which represents government and has a mandate to promote wines abroad and to develop research and technology for the advancement of the wine industry (SAWIT 2002). Other bodies conducting research and providing extension are the South African Wine Institute, and the South African Wine Industry Information and Systems (SAWIS) body.

\section{Australia}

The Australian wine industry can be traced back to its very humble beginnings in the 1790s under Governor Phillip at Rose Hill, NSW. The first vintage report was that 'the grape thrives remarkably well' (Beeston 1994). By 1795 the first vineyard had produced 410 litres of wine and it was predicted that within two years there would be no need for importation (Beeston 1994).

However, vine plantings around the western area of Sydney were sporadic and of mixed success for the next 40 years, until the cause was taken up seriously by a new immigrant James Busby. Today the industry is a leading producer and exporter (now $4^{\text {th }}$ largest) with growth rates outstripping most, if not all its rivals.

Between 2000 and 2001

- The number of wineries increased by $11 \%$ to 1465

- Area under vine increased by $6 \%$ to 148,275 hectares

- $\quad$ Tonnes crushed increased by $24.5 \%$ to $1,426,323$ 
- Beverage production increased $28.3 \%$ to $1,034.8$ million litres

- Exports increased $21 \%$ to 375.1 million litres - in value, $18.9 \%$ to $\$ 1,764,200$

(Winetitles, 2002)

\section{Research and Development}

Research and Development in the Australian wine industry is promoted and coordinated through the GWRDC, a nationally established and funded body, with a mandate to address industry-wide research priorities in collaboration with co-investors.

R\&D targeted by the GWRDC is then carried out by qualified and endorsed providers. These include the Australian Wine Research Institute (AWRI), the CSIRO, State departments of agriculture and universities. The GWRDC also consults extensively with other providers such as the Australian Wine and Brandy Corporation and the Cooperative Research Centre for Viticulture (CRCV) (GWRDC Home Page, 2002).

GWRDC Research program priorities derive from industry needs, as presented in their fiveyear plan and are funded through an industry levy on tonnes of grapes crushed and litres of wine produced. All wine operators are subject to this levy.

\section{New Zealand}

The New Zealand wine industry can be traced back to 1819 when vines were first planted, followed by the building of the first winery in Hawke's Bay in 1851. The relatively short history can be largely attributed to a Temperance Society and very conservative licensing laws in existence until the middle of the $19^{\text {th }}$ century. (Network Wine Agency 2002)

Recent times however, have seen a rapid expansion of the industry, with the number of wine regions increasing from a mere 97 in 1984 to 382 in 2001. Exports have quadrupled in the 
last decade alone, with their value increasing eight-fold. These exports now account for $34 \%$ of NZ wine sales. In 2003 it is expected there will be approximately 15,000 hectares under vine, producing more than 71,000 tonnes (Network Wine Agency, 2002)

\section{Research and Development}

Research and Development in the New Zealand wine industry was until recently, coordinated and promoted by two industry bodies, sponsored jointly by industry and the government. These were the Wine Institute of New Zealand and the New Zealand Grape Growers Council, which together represented the interests of New Zealand's wine operators in terms of research, information dissemination, operator representation, export support and industry standards (Network Wine Agency, 2002).

As of the $1^{\text {st }}$ March, 2002, these two bodies have merged to form a new organisation - the New Zealand Winegrowers. This body will carry on the same responsibilities of the previous two, but will have greater funding scope, greater representative powers and a broader mandate. (NZ Winegrowers Annual Report, 2002).

\section{Findings}

\section{Perceptions of R\&D levels within New World Wine Industries}

There was a diversity of responses to the issue of R\&D levels within New World wine industries. Recipients were asked to comment on what they considered the overall level of R\&D within their own wine industry to be. Of the total 114 who responded, 30 stated that it could only be rated as 'low'. Another 48 rated their industry's R\&D level as 'average', while 36 claimed that it was 'excellent' or 'high'. 
Responses on Overall Level of R\&D within Industry

\begin{tabular}{|c|c|c|}
\hline$\underline{\text { Low }}$ & $\underline{\text { Average }}$ & High \\
\hline $26.3 \%$ & $42.1 \%$ & $26.3 \%$ \\
\hline
\end{tabular}

While the above responses represent a fairly even distribution of opinion, they mask the industry specific opinions. If we break responses down by the four New World industries we see a very different story.

Operator Perceptions of Overall R\&D in their Own Industry (\% terms)

\begin{tabular}{|c|c|c|c|}
\hline Industry & Low & Average & High \\
\hline $\begin{array}{c}\text { California } \\
(\mathrm{n}=22)\end{array}$ & $36.3 \%$ & $54.5 \%$ & $9.0 \%$ \\
\hline $\begin{array}{c}\text { South Africa } \\
(\mathrm{n}=16)\end{array}$ & $12.5 \%$ & $62.5 \%$ & $25.0 \%$ \\
\hline $\begin{array}{c}\text { Australia } \\
(\mathrm{n}=47)\end{array}$ & $19.1 \%$ & $23.4 \%$ & $57.4 \%$ \\
\hline $\begin{array}{c}\text { New Zealand } \\
(\mathrm{n}=29)\end{array}$ & $37.9 \%$ & $51.7 \%$ & $10.3 \%$ \\
\hline
\end{tabular}

These figures clearly reflect the opinion by Australian wine operators that R\&D levels in their industry are well above the average. In contrast, New Zealand and Californian operators view R\&D levels as below the average, with very few operators rating levels as 'high'.

\section{Coordination of R\&D within New World Industries}

The next issue to be examined was the perception of how well this R\&D was actually coordinated within each of the industries. R\&D studies generally, and a wine R\&D study in particular, previously carried out by the author have shown that while overall R\&D levels within a specific industry sector may be high, its effectiveness depends on the adequacy of mechanisms and structures for its transmission across the sector (Aylward, 2002, Mohannak 
\& Aylward, 2002). The level of R\&D coordination within an industry usually provides a fairly clear indication of the industry's R\&D infrastructure and support services.

Again, examining the total operator population, we see that of the 109 operators who responded to this question, 24 thought that $R \& D$ was coordinated 'poorly' within their industry. A strong majority of 67 thought it was coordinated 'moderately' and only 18 thought there was a high degree of coordination. These levels roughly equate, in Australia at least, with a number of the agriculture and manufacturing sectors, but what is important is how well matched this coordination is with levels of R\&D within each of the New World industries.

Perceived Effectiveness of $R \& D$ Coordination within each of the New World Industries

\begin{tabular}{|c|c|c|c|}
\hline Industry & Poorly & $\underline{\text { Moderately }}$ & Very \\
\hline $\begin{array}{c}\text { California } \\
(\mathrm{n}=20)\end{array}$ & $40 \%$ & $50.0 \%$ & $10 \%$ \\
\hline $\begin{array}{c}\text { South Africa } \\
(\mathrm{n}=16)\end{array}$ & $25 \%$ & $68.8 \%$ & $6.2 \%$ \\
\hline $\begin{array}{c}\text { Australia } \\
(\mathrm{n}=47)\end{array}$ & $2.1 \%$ & $65.9 \%$ & $31.9 \%$ \\
\hline $\begin{array}{c}\text { New Zealand } \\
(\mathrm{n}=27)\end{array}$ & $42.4 \%$ & $57.6 \%$ & $0.0 \%$ \\
\hline
\end{tabular}

It is very clear from the above table that Australian wine operators believe that overall, their $R \& D$ is fairly well coordinated. What is even more apparent, is that the Australian coordination of R\&D is seen as well above the average for the selected New World industries and more importantly, is believed to be appropriately matched to its overall level of R\&D. At the other end of the scale, New Zealand operators believe that the coordination of R\&D within their industry is relatively poor, and that this underperformance is well matched to its low level of overall R\&D. 


\section{Industry Information Concerning Developments in R\&D: Relevance and Availability}

Integral to the coordination of $R \& D$ within an industry sector, is the information flow between industry bodies and operators. One could assume that, all things being equal, the more centralised the structure and mechanisms of R\&D diffusion within an industry sector, the more regular and effective the information flow. Certainly the Australian wine industry is one of the more centralised of the New World industries in terms of research priority setting, research funding and mechanisms of diffusion.

The table below demonstrates that there is an association between information flows within each industry and the level of R\&D coordination. Australia again stands out with the significant majority of operators claiming that the information flow within their industry is 'regular' and 'relevant' to their needs. This is not the case for operators within the other three industries who report with a high degree of consensus that their information is largely 'irregular'. This finding is as expected, given previous findings.

There is also a close association between the consistency/relevance of information in Australia, and the degree of R\&D centralisation. Again, however, there is relatively little association among the other three industries, so no assumptions can be made. While the New Zealand wine industry is also relatively centralised, it ranks fairly poorly in terms of R\&D coordination and information flows. Conversely, $R \& D$ in the Californian wine industry is one of the more decentralised, with a large number of stakeholders contributing in varied ways, yet coordination of R\&D is ranked similarly to that of New Zealand and South Africa. 


\begin{tabular}{|c|c|c|c|}
\hline$\underline{\text { Industry }}$ & $\underline{\text { Non-existent }}$ & $\underline{\text { Irregular }}$ & $\underline{\text { Regular \& Relevant }}$ \\
\hline California (n=20) & $5.0 \%$ & $55.0 \%$ & $40.0 \%$ \\
\hline S. Africa (n=16) & $0.0 \%$ & $62.5 \%$ & $37.5 \%$ \\
\hline Australia (n=47) & $2.1 \%$ & $23.4 \%$ & $74.5 \%$ \\
\hline N Z (n=28) & $3.6 \%$ & $53.6 \%$ & $42.6 \%$ \\
\hline
\end{tabular}

\section{Operator Perceptions of their Respective Industry Bodies}

For a clearer understanding of the above statistics, we need to dissect the information further by looking at perceptions of how well each of the New World industry bodies service operator needs.

Californian Operator Perceptions of Service by Industry Bodies (Nos)

\begin{tabular}{|c|c|c|c|c|c|}
\hline Industry Body & Not at All & Not Well & Average & $\underline{\text { Well }}$ & Very Well \\
\hline $\begin{array}{c}\text { California Assoc. } \\
\text { WineGrape Growers }\end{array}$ & 1 & 6 & 10 & 5 & \\
\hline $\begin{array}{c}\text { American Vineyard } \\
\text { Foundation }\end{array}$ & 1 & 4 & 8 & 5 & 3 \\
\hline $\begin{array}{c}\text { American Vintners } \\
\text { Assoc. }\end{array}$ & 1 & 4 & 12 & 4 & \\
\hline
\end{tabular}

Note: One of the major research bodies servicing the Californian wine industry is the University of California-Davis, which conducts some of the world's best viticultural and oenological research. It is not however, a so-called industry body and therefore cannot be a subject of this study.

Overall, Californian wine operators do not believe that they are serviced particularly well by their industry bodies. Only 22\% of respondents believed that the California Association of WineGrape Growers serviced their research needs well. For the American Vineyard Foundation, the responses were somewhat better, with $38 \%$ of respondents claiming that their 
needs were well serviced. For the American Vintners Association however, results were poor.

Only $19 \%$ believed they were serviced well.

South African Operator Perceptions of Service by Industry Bodies (Nos)

\begin{tabular}{|c|c|c|c|c|c|}
\hline Industry Body & Not at All & Not Well & Average & Well & Very Well \\
\hline $\begin{array}{c}\text { Nietvoorbij } \\
\text { Institute }\end{array}$ & 1 & 6 & 6 & 3 & \\
\hline $\begin{array}{c}\text { SA Wine Industry } \\
\text { Information \& } \\
\text { Systems }\end{array}$ & & 6 & 6 & 9 & 1 \\
\hline
\end{tabular}

As is clear from the above table, the Nietvoorbij Institute for Viticulture and Oenology is not very well regarded among the country's wine operators. Only $18 \%$ believed that it serviced their needs well, while $43 \%$ believed that it failed to service their needs adequately. There was a very different story for the South African wine industry Information and Systems body wherein $62 \%$ believed it serviced their needs 'well' or 'very well' and no operator thought it failed to service their needs.

Australian Operator Perceptions of Service by Industry Bodies (Nos)

\begin{tabular}{|c|c|c|c|c|c|}
\hline Industry Body & Not at All & Not Well & Average & Well & Very Well \\
\hline $\begin{array}{c}\text { Grape \& Wine R\&D } \\
\text { Corporation }\end{array}$ & 1 & 2 & 15 & 24 & 5 \\
\hline $\begin{array}{c}\text { Australian Wine } \\
\text { Research Institute }\end{array}$ & 2 & 4 & 8 & 17 & 14 \\
\hline
\end{tabular}

As the above table demonstrates, both these industry bodies are held in fairly high regard by Australian wine operators. Of the 47 operators who commented on the services of the GWRDC, 29 (61.7\%) claimed that they were serviced either 'well' or 'very well' by it. The figures are even more impressive for the Australian Wine Research Institute, for which 31 of the 45 respondents (69\%) claimed they were serviced either 'well' or 'very well'. 


\begin{tabular}{|c|c|c|c|c|c|}
\hline Industry Body & Not at All & Not Well & Average & Well & Very Well \\
\hline $\begin{array}{c}\text { Wine Institute } \\
\text { Of NZ }\end{array}$ & 5 & 3 & 5 & 10 & 7 \\
\hline $\begin{array}{c}\text { NZ } \\
\text { Grapegrowers } \\
\text { Council }\end{array}$ & 9 & 4 & 5 & 8 & 4 \\
\hline
\end{tabular}

The above table shows mixed responses to the issue of how well New Zealand wine operators are serviced by their industry R\&D bodies. It is also somewhat at odds with operators' attitude towards the level of R\&D coordination and information flow within their industry. 17 of the 30 respondents (56\%) claim that the Wine Institute of New Zealand services them 'well' or 'very well', while another $8(26 \%)$ claim that it does not service them well or even at all.

For the New Zealand Grapegrowers Council the responses were less positive. 12 of the 30 responses (40\%) claim they were serviced 'well' or 'very well', while another $13(43 \%)$ claim that service was poor. Perhaps the new amalgamation will help to create greater coordination and consistency within the industry.

It should be noted that overall, many of the respondents who claimed they had either not been serviced at all or had not been serviced well, were boutique or small operators in regional areas. The author's previous study (Aylward, 2002) highlighted the fact that at least in Australia small, regional operators were serviced less by industry bodies in general and research bodies in particular. There are two main explanations for this. One relates to what the previous study referred to as the R\&D 'epicentre' - a geographical and cultural concentration of the industry's R\&D providers, users and other stakeholders. Much of the research, innovation and investment remains within these concentrations and so does not allow for a consistent or equal diffusion of knowledge/innovation to regional operators. 
The other explanation, also highlighted in the previous study, relates to the issue of 'innovative inertia', where, through a number of circumstances such as lack of awareness $\&$ knowledge, lack of time, finance, and management priorities, small operators enter the 'innovation circle' less frequently and under less rewarding circumstances than their larger counterparts.

The combination of these barriers remain the largest impediment to a uniform take-up and transmission of innovation among New World industries.

\section{R\&D Infrastructure and Support - Operator Rankings}

In the final section of the study, we asked operators from each of the selected New World industries to rank their own industry (of four selected New World industries) in terms of their overall $\mathrm{R} \& \mathrm{D}$ infrastructure, and the research support services they provide to operators.

Operator Rankings of Own Industry for Overall R\&D Infrastructure/Support

\begin{tabular}{|c|c|c|c|c|c|}
\hline$\underline{\text { Industry }}$ & Ranked 1st & Ranked 2nd & Ranked 3rd & Ranked 4th & Total Ranked \\
\hline California & 0 & 5 & 13 & 2 & $\mathbf{2 0}$ \\
\hline South Africa & 0 & 0 & 10 & 5 & $\mathbf{1 5}$ \\
\hline Australia & 20 & 13 & 7 & 0 & $\mathbf{4 0}$ \\
\hline New Zealand & 0 & 0 & 12 & 11 & $\mathbf{2 3}$ \\
\hline
\end{tabular}

The above table provides for some interesting reading. As we look at the list of New World industries, we see that Australian operators were the only ones to rank their industry as first among the four. Twenty Australian operators, or exactly 50\% believed that R\&D infrastructure in the Australian wine industry was the best of the four selected industries. Another $13(32.5 \%)$ ranked it as second and no operator ranked it last. 
With the rankings of New Zealand operators however, the story is almost the reverse. No NZ operator ranked their industry first or second, 12 (52\%) ranked it third and $11(48 \%)$ ranked it last. The responses were very similar from South African operators. Again, no South African operator ranked their own industry first or second, but $10(66 \%)$ ranked it third and $5(33 \%)$ ranked it last. California fared slightly better with its operators. There were no 'first' rankings, but $5(25 \%)$ ranked it second, $13(65 \%)$ third and $2(1 \%)$ last.

It is apparent from these figures that Australian operators are far more impressed with the infrastructure and support for innovation within their industry than their New World peers with theirs.

\section{Perceptions of New World Leadership}

In order to get a more 'objective' idea of where each industry ranks, all respondents were asked to nominate the New World industry they believed led the field in terms of overall R\&D.

Who leads the New World Industries in terms of Overall $R \& D ?(N=100)$

\begin{tabular}{|c|c|}
\hline Industry & Percentage \\
\hline California & $31 \%$ \\
\hline South Africa & $2 \%$ \\
\hline Australia & $64 \%$ \\
\hline New Zealand & $3 \%$ \\
\hline
\end{tabular}

Note: While an initial observation of the figures suggests that there may be a bias towards Australia due to the higher number of Australian respondents in the study, when we break the figures down, we see that this bias does not in fact, exist. Less than a third (20 operators or $31 \%$ ) of those who ranked Australia first, were actually Australian operators. In comparison, 
$56 \%$ of Californians ranked Australia first, over $76 \%$ of South Africans ranked Australia first, and $37 \%$ of New Zealand operators ranked Australia first.

It is clear from these figures that the vast majority of respondents rated Australian R\&D as a leader among the sample group. These figures are also consistent with Australian operator perceptions of their industry in terms of overall R\&D levels and the coordination of that R\&D. What is important about the above figures, is the perceived strength of that leadership.

\section{Concluding Remarks}

It is apparent that while the New World wine industries are bringing significant changes to the global wine landscape in terms of the way wine is grown, produced and marketed, the R\&D 'models' used to support these industries are quite different.

A number of innovation territories, such as levels of R\&D infrastructure, interaction, coordination and transmission, appear to vary significantly between the four New World industries in this study. Operators within the New Zealand wine industry for example, believe that these territories are weakly related and the mechanisms quite poor. In Australia on the other hand the interaction between territories and the mechanisms used are seen as quite effective.

The size of the industry and the degree to which it is centralised appear to have little to do with the coordination of R\&D/innovation. New Zealand and Australia are both small and highly centralised, yet are at opposite ends of the scale in terms of R\&D coordination. The Californian industry is also more coordinated than New Zealand, yet is far less centralised.

What is clearer, however, is that the effectiveness of these innovation territories and mechanisms are determined to a large extent by funding structures and the applicability of 
that funding to R\&D. Australia's operator levy for R\&D is among the highest in the world and the fact that it is channelled through a single industry body, the GWRDC before being distributed to various research organisations ensures that the coordination of that $R \& D$ remains high. This is clear from not only Australian operator perceptions, but also from operator perceptions among the other New World industries.

The general perception among New World wine operators in this sample that Australia is at the leading edge of the New World in $\mathrm{R} \& \mathrm{D} /$ innovation is increasingly apparent. Although this can only be interpreted as indicative, it illustrates fairly clearly the different approach to, and preparedness for uptake of, R\&D among the New World industries. One certainty is, that while innovation is just one of many elements contributing to the success of the New World wine industry, the dynamic, growth-oriented nature of this industry continues to keep it in the research spotlight. 


\section{References}

Anderson, K. (1999) Australia's Grape and Wine Industry into the $21^{\text {st }}$ Century, CIES Discussion Paper, Adelaide, 99/24, p.5.

Anderson, K. (2000), Lessons for Other Industries From Australia's Booming Wine Industry, Policy Discussion paper No. 0025, Centre for International Economic Studies, SA. From CIES website.

Anderson, K. (2001), Where in the World is the Wine Industry Going? Discussion paper No. 0101, Centre for International Economic Studies, SA. From CIES website.

Anderson, K., D. Norman and G. Wittwer (2002) Globalization of the world's wine markets, Invited paper for the Australian Conference of Economists, Adelaide, September, p.5

ARC infruitec-Neitvoorbij (2002) www.arc.agric.za/institutes/infruit/main/intro.htm.

American Vineyard Foundation (2002) www.avf.org/history.html.

Aylward, D. (2002), Diffusion of R\&D within the Australian Wine Industry, in:

Prometheus, vol. 2, no. 4, pp. 351-366.

Beeston, J., (1994) A Concise History of Australian Wine,. Sydney: Allen \& Unwin, p. 4.

Californian Wine Institute (2002) Online data, www.wineinstitute.org/.

CAWG (2002) www.cawg.org/about/index.htm.

CRCV (2002) www.crcv.com.au/.

GWRDC (2001) Annual Report 2000-2001, Canberra: GWRDC.

GWRDC (2002) www.gwrdc.com.au/.

GWRDC (2002) Newsletter, 4, 1 [April].

Lundvall, B. (1999) National business systems and national systems of innovation, International Studies of Management \& Organisation, 29 (2), 60-77.

Marceau, Jane and Cristina Martinez-Fernandez (2002), 'Territorial Systems and Highways of Innovation in Australia: A Critical Approach for Research and Policy Development', paper presented to the conference Innovation and Regional Development: Competing for the Future, University of Ballarat, 22-23 August 2002.

Mohannak, Kavoos, and David Aylward (2002), Regional innovation: experiences of small firms in non-metropolitan Australia, in T. Turpin, Liu Xielin, S. garrett-Jones and P. Burns (eds), Innovation, Technology Policy and regional development: Evidence from China and Australia, Edward Elgar: Cheltenham, UK and Northampton, MA.

Mojave Internet (2002), Wine and Travel California - History, 66.155.15.212/site_4/slo_history.htm.

SAWIS (2002) www.sawis.co.za/eng/public/HomePage.asp. 
South African Wine (2002) Winenet, www.wine.co.za.

Wine America 2002 www.americanwineries.org/

Wine and Travel California (2002) History, www.66.155.15.212/site_4/slo_history.htm

Wines of South Africa (2002) www.wosa.co.za.

Wine Institute Online (2001) The Voice of California Wine, World Wine Statistics, Dec.

Wine Online (2001) www.winetitles.com.au/awol/ Nov.

Wine New Zealand (2002) www.winenewzealand.com.

New Zealand Wine (2002) http://www.nzwine.com/intro/.

Winetitles (2002) The Australian and New Zealand Wine Industry Directory, Winetitles.

Winetitles (2001) The Australian \& NZ Wine Directory, Winetitles, $19^{\text {th }}$ Annual Edition, p. 5. 